Makale Türü: Araştırma Makalesi

\title{
MERET OPPENHEIM VE HEYKELLERİ
}

\author{
Ümmügülsüm SOYSÜREN ${ }^{1}$, Canan ZÖNGÜR²
}

\begin{abstract}
ÖZ
20. yüzyll, sanatın felsefi ve edebi yönden sorgulandı $\breve{l}$ ve kırılmaların yaşandı $\breve{l}$ bir dönem olarak tarihe geçmiştir. Meret Oppenheim bu tartışmaların içinde sanat hayatına başlamıştır. Kadının rolünün aile ile sınırlandığl, seçme- seçilme hakkının bile olmadı̆̆ toplumsal bir ortamda sanat çalışmalarını sürdürmüşür. Sanatçı, sanat dünyasının da kadına aynı rolleri yüklediğini ve sanat çevresinin toplumun diğer kesimlerinden farklı olmadığını gözlemlemiştir. Bu durum onu hayal kırıklı̆̆ına uğratmıştır. Bu bağlamda sanat ve sanatın içinde kadın sanatçı olarak var olma mücadelesi vermiştir. Kadın ve kadın sanatçı olmanın yarattı̆̆ psikolojik sorunlarla mücadele ederken, Yahudi bir babanın kızı olarak Ikinci Dünya Savaşı'nın sıkıntılarını da bizzat yaşamıştır. Bu çalışmada Meret Oppenheim’ın Sürrealizmle başlayıp, farklılaşarak ölümüne kadar devam eden sanatsal süreci incelenmiştir. Yöntem olarak literatür taraması yapılmış, sanatçı hakkında yayımlanan kaynaklar taranmış ve eserlerinin sergilendiği sergi ve kataloglar araştırılmıştır. Sanatçının rüyaları, hayalleri, Carl Gustav Jung'un Analitik Psikolojisi ve arketiplerinden referans alarak somutlaştırdı ğ eserleri incelenmiştir. Aynı zamanda 'kadın sanatı mı? sanat mı? kadın sanatçı mı? gibi sorgulamaları ortaya çıkaran çalışmaları ve sanatsal yaşamı üzerinden değerlendirilmiştir.
\end{abstract}

Anahtar Kelimeler: Sürrealizm, Bilinçaltı, Ruhsal Otomatizm, Sürrealist Nesne, Meret Oppenheim

\footnotetext{
${ }^{1}$ Yüksek Lisans Öğrencisi, Muğla Sıtkı Koçman Üniversitesi, Güzel Sanatlar Fakültesi, ORCID NO: 00000003-1619-982X, gulsumsoysuren63@gmail.com

2 Doç. Dr. Muğla Sıtkı Koçman Üniversitesi, Güzel Sanatlar Fakültesi, ORCID NO: 0000-0002-5665-0112, csonmezdag@gmail.com
}

Makale Geliș Tarihi: 1 Haziran 2021 Kabul Tarihi: 18 Aralık 2021 


\title{
MERET OPPENHEIM AND HER STATUES
}

\begin{abstract}
The 20th century went down in history as a period in which art was questioned in terms of philosophy and literature, and fractures were experienced. Meret Oppenheim started her art carreer in these arguements. She continued her art studies in the social environment in which the role of women was restricted within the family and had even no right to vote. The artist observed that the art world also assigns the same roles to women and that the art environment is not different from other segments of society. So, she was disappointed. In this context, she struggled to survive as a woman. She suffered from psychological problems of being a woman and a woman artist. While she was struggling, she experienced the troubles of World War II personally as being the daughter of a Jewish father. In this work, Meret Oppenheims artistic period, which started with surrealism and continued with differentiations until her death, has been studied. As a method, literature was searched, the sources published about the artist were scanned, and the exhibitions and catalogs where her works were exhibited were searched. Her dreams have been studied through her works that she incarnated referring from Carl Gustav Jung's Analytical Psychology and archetypes. Meanwhile, she has been evaluated through her artistic life and works which arose the questioning such as 'Is it woman art? Is it art? Is it a woman artist?
\end{abstract}

Keywords: Surrealism, Subconscious, Spiritual Automatism, Surrealist Object, Meret Oppenheim 


\section{Giriş}

Meret Oppenheim'ın sanatını kavrayabilmek için onun yaşadığı dönemi, toplumu dolayısıyla sanatsal üretimi derinden etkileyen savaşlardan ve toplumsal dönüşümlerden haberdar olmak gerekmektedir. Oppenheim'ın doğumundan sadece bir y1l sonra 1914'te başlayıp 1918'de sona eren Birinci Dünya Savaşı, pek çok ülkenin katıldığı kitlesel anlamda ilk büyük savaştır. Teknolojik buluşların, kitlesel imha araçların ilk defa kullanılıp denendiği bu savaş, milyonlarca insanın ölümüne bir o kadar da insanın sakatlanmasına, imparatorlukların yıkılıp sınırların değişimine ve yeni devletlerin kurulmasına neden olmuştur. Savaşın yarattığı maddi ve manevi yıkım, insan aklına olan güveni sarsmış, var olan tüm değerlerin sorgulanmasına yol açmıştır. Bu sorgulamaların, sanat alanındaki önemli yansıması kuşkusuz Dada (1916) hareketidir. Dada sosyal ve kültürel anlamda insan yaratıcılığını sınırlayan, sorgulanmadan kabul gören boş değerleri tartışmaya açan bir karşı sanat hareketidir. Dadacılar dünyayı savaşa sürükleyen insan aklının tükenmişliğini, içi boş değerleri ve bütün bunları oluşturan sistemi eleştirmişlerdir. Dada hareketi disiplinler arası eylemleriyle sanatın sınırlarını da genişletmiş ve kendinden sonraki tüm akımları etkilemiştir. Bu hareket içinde şair Tristan Tzara, Raoul Hausmann, Marcel Duchamp'ın yanı sıra daha sonra Sürrealist akımın içinde yer alacak Man Ray ve Hans Arp da bulunmaktadır.

1920'li yıllarda her şeye hatta kendine karşı olan Dadanın görüşlerini, elle tutulur bir üretime dönüştüren Sürrealizm akımı filizlenmeye başlamıştır. Sürrealizm terimini ilk kullanan Fransız şair Guillaume Apollinaire'dır. Antmen'e (2017) göre, “Apollinaire, bu sözcüğü 1917 tarihli oyunu “Tirésias'ın Memeleri”yle, Picasso'nun sahne tasarımını yaptığı "Geçit" başlıklı baleyi anlatırken kullanmıştır" (s. 133).

Birinci Dünya Savaşı sırasında bir nöroloji koğuşunda çalışan Fransız doktor, şair ve yazar olan André Breton Sürrealizm akımını yönlendiren kültür aktörlerden biridir. Breton 1924 yılında "Sürrealist Manifesto" metnini yayımlamıştır. Bu manifestoyu dış etkenlerle ilişkili olmayan, tümüyle doğal bir eylem olarak tanımlamıştır. Sürrealizm burjuva değer yargılarına ve geleneksel sanat anlayışına karşı olduğu için aynı zamanda Dadanın devamı gibi görülmüştür. Sürrealistleri Dadadan ayıran en önemli fark resme ve düşlere önem vermeleridir. Dadanın peşi sıra doğan Sürrealizmi sanatta bir devrim olarak gören Y1lmaz (2013): "Modernizmin saf-soyut-nesnesiz sanat idealini delen, geçersiz kılan; buna karşın ısrarla sanatın dışına itilen figür, nesne, öykü, düş, ahlak, cinsellik ve daha ne varsa hepsini içeri alan bir devrimdir" der (s. 2020). Yılmaz bu devrimin sanatta "Avrupa egemenliğinin sonu ve Amerikan egemenliğinin başlangıcının, özetle postmodern durumun işareti” olduğunu da belirtir (s. 202). Sürrealistlere göre bireydeki yaratıcılığın gelişmesini engelleyen sorunlardan biri toplumsal kurallardır. Bu sorunun çözümünü psikanaliz biliminin kurucusu olan Sigmund Freud'un düşüncelerinde aramışlardır. Timuçin (2014): "Freud'un çalışmalarıyla yakından ilgilen Breton Sürrealizmi, düşüncenin gerçek işleyişini sözle, yazıyla ya da bir başka yolla açıklama olanağı veren arı ruhsal boşalım olarak tanımlamıştır" (s. 148). 
Sürrealist sanatçıların ifade biçimi ruhsal otomatizmdir. Ruhsal otomatizm bir mantık çerçevesinde belli bir estetik ya da ahlaki ön yargı kontrolü olmadan düşüncenin aktarımıdır. Sanatçı bilincin ötesine, arzuların ve kaygıların gerçek kaynağına iner, sanatsal yaratım sürecini oluşturur. Antmen (2017) ise "Sürrealist sanatçının imgesinin özünün doğaçlamaya dayanan yaratı sürecinin üstünlüğü olduğunu” belirtir (s. 136). Danto (2013), Breton'un bilinçaltını epistemolojik bir açıdan değerlendirdiğini vurgular. "Breton'a göre bilinçaltı, irtibatı kaybettiğimiz bir dünyanın sırlarını açığa çıkaran bilişsel organ gibidir. Yani otomatizm bizi yalnızca bilinçaltına ulaştırmakla kalmaz, bilinçaltı aracılığıyla onun iletişim halinde olduğu dünyaya girebilmemizi, gerçeği aşıp gerçeküstüne erişmemizi sağlar" (s. 28).

20. yüzyıl sanatın ne olduğuna ilişkin felsefi sorgulamaların ve kırılmaların yaşandığı bir dönemdir. Örneğin, “anti sanat” terimini ilk kez kullanan Marcel Duchamp'ın hazır nesne ile oluşturduğu eserlerinde "sanatı yetenek ve beceri eyleminden düşünme eylemine çevirmiştir" (Antmen, 2017, s. 125). Dadayla sanata dâhil edilen hazır nesne, Sürrealistler tarafından da sanatsal ifade biçimi olarak kullanılmıştır. Dadacılar gibi Sürrealistler de sanatın sınırlandırılmasına karşı çıkmışlardır. Bu bağlamda Sürrealistler, estetik hazzın ötesine geçmiş, insanların yaşamlarını etkilemiş nesneleri farklı şekillerde görmelerini sağlamışlardır. Salvador Dali, Alberto Giacometti ve Meret Oppenheim gibi sanatçılar yarattıkları Sürrealist heykellerle bu alanda öncü durumuna gelmişlerdir. Bu sanatçılar bilinçsiz gereksinimlere uyan nesneyi dış dünyada bulmuş, iç ve dış gerçeklik arasındaki bağıntıları yeniden yorumlayarak eserlerine yansıtmışlardır. Hopkins (2020), Meret Oppenheim, Salvador Dali ve Alberto Giacometti' in Sürrealist nesnelerinin "gerçek bir kült” olduğunu ifade eder (s. 42).

Kadının görevlerinin aile içinde sınırlandığı, tanımlandığ olmadığı toplumsal bir ortamda, sanat dünyası da farklı görünmemektedir. Sanat dünyası kadınları, erkek yaratıcılığının gerçekleşmesini sağlayan tamamlayıcı unsur olarak görüyor, kadınlardan erkek sanatçıların eşleri, sevgilileri ya da ilham perileri olmaları isteniyordu (Hopkins, 2020, s. 170). Bu toplumsal yapılanmada Meret Oppenheim cinsiyetiyle ilgili sabit fikirlere meydan okumuş; toplumsal cinsiyet tabularıyla dalga geçen yaşam tarzıyla kamusal bir figür olmuştur. Bu çalışma, sanatçının duygusal yapısının yansımaları olan eserleri, istenmeyeni görünür hale getirme çabasındaki mizahi yaklaşımı ve olgunluk döneminde sanat üretimindeki değişimler göz önüne alınarak şekillenmiştir. Bu şekillendirmede sanatçının Sürrealist çalışmaları ve olgunluk dönemini işaret eden heykelleri dikkate alınmıştır. Sanatçının çalışmalarının temelini oluşturan rüyaları, bilinçaltı, cinsel tercihi, doğa, kadınlık olgusu ve sanatsal sorgulaması, Carl Gustav Jung'un Analitik Psikolojisi ve arketipleri göz önüne alınarak eserleri üzerinden değerlendirilip, analiz edilmiştir. Bu bağlamda Oppenheim'ın Sürrealizmle başladığı sanat çalışmaları, zaman ve toplumsal dinamiklerin etkisiyle değişiminin evreleri göz önüne alınmış ve bu bilgiler literatür taraması yapılarak toplanmıştır. "Kadın sanatısanat" ikilemi üzerinden "kadın sanatçı" yerine "sanatçı" olarak var olabilme çabası 
incelenmiş, Oppenheim'ın eserleri hakkında veri toplanması ve yorumlanması yöntem olarak kullanılmıştır.

\section{Meret Oppenheim}

Sürrealist akımının önemli kadın sanatçılarından biri olan Oppenheim sanat ve felsefeyle iç içe olan bir aile ortamında büyümüştür. Alman asıllı İsveçli olan Oppenheim (19131985) elli beş yıllık sanat yolculuğunda, sanatın her dalında eser üretmiştir. Mobilya, kostüm, resim, şiir, heykel ve heykele dönüşen takılar tasarlamış, sanat dalları arasında ayrım yapmadan fikirlerini kendine has yapısıyla şaşırtıcı biçimlerde hayata geçirmiştir. Oppenheim'ın sanatla ilk teması çocukluk döneminde başlamıştır. Çocuk öyküleri yazan büyükannesi hayallerinin beslenip güçlenmesini sağlamıştır. Büyükannesi Lisa Wenger, Düsseldorf Sanat Akademisine giren ilk kadınlardan biri, kadın hakları savunucusu ve tanınmış bir yazardır. Ailesinin entelektüel çevresi sanatçının erken yaşta, sanat ve felsefeyle tanışmasını sağlamıştır. Babası, Jung'un düşüncelerini önemseyen bir doktordur. Oppenheim on dört yaşından itibaren rüyalarını, hayallerini kendisi için önemli olan her şeyi yazmaya başlamıştır (Curiger, 2013). Bu eylem Jung'tan etkilenen babasının önerisidir (Darcella ve Galopin, 2018). Yazma eylemi Oppenheim'ın sanatçı olmaya karar verdiğinde, sanat yaşamının şekillenmesinde önemli olmuştur. On sekiz yaşında sanatçı olmak için Paris'e gitme kararlılığı, oluşmaya başlayan sanatçı kimliğinin ipuçlarını vermiştir. Büyükannesinden beslenen çocukluğu engin hayal gücünü oluşturmuş, rüyalarıyla birlikte bunları sanatına aktarma yöntemleri bularak sanatını beslemiştir. Jung'un psikanaliz öğretisi yaşam ve sanat yolculuğunun başaktörü olmuştur. Eserlerinde gündelik gerçekliğe göndermeler yapmış, göndermelerini yorumlarken cesur ve garip dünyasının kapılarını aralamıştır. Dönemin koşullarına göre özgürlügüune ve yaşamında söz hakkının sadece kendisine ait olması tavrıyla, sanatta da özgün bir kişilik olmuştur (Özer, 2019). Kadın ve erkek sanatçı sınıflandırmasına karşı gelmiş, cinsiyetten bağımsız olarak sadece sanatçı varlığını kabul etmiştir (Gommel, 2013).

\section{Oppenheim'ın Sürrealist Çalışmaları}

Oppenheim sanat eğitimi için 1931'de Paris'e gitmiş ve Sürrealist çalışmalar üreten Alberto Giacometti'yle tanışmıştır (Passerons, 1982, s. 218). "Salon des Surindépendants" sergisine davet edildiğinde ise Andre Breton'la tanışmıştır. Bu tanışma Sürrealist çevreye girişinin ilk adımı olmuştur. Çevresinde Pablo Picasso, Marcel Duchamp, Marx Ernst, Francis Picabia ve asistanlığını da yaptı̆̆ı Man Ray gibi sanatçılar yer almıştır. Döneme damgasını vuran bu sanatçılar, onun sanat anlayışının şekillenmesinde etkili olmuşlardır. Oppenheim, Jung'un arketiplerinden referans alarak eserlerini üretmiştir. Arketipler Platon'un idealarının benzeridir. Platon'un ideası yüce ve tamlık örneğiyken; Jung'un arketipi ise iki kutupludur. İyi-kötü, karanlık-aydınlık gibi zıtların bütünüdür. Jung'a (2006) göre, “Arketipin anlamı tam tanımlanamaz ve 
metafizikseldir. Arketipler bilincin ötesine aittir ve ruhtan kaynaklanır. Bilinç tarafindan algılansa da algılanmasa da vardırlar” (s. 48-50). Sanatçıyı özellikle Jung'un anima ve animus arketipi öğretisi etkilemiştir. "Anima erkeğin bilinçdışının kadınsı yanı animus ise kadının bilinçdışının erkeksi yanıdır” (s. 404). Jung'un öğretilerinden etkilenerek rüyalarını yazmış ve onları çözümleyerek düşsel eserlere dönüştürmüştür. Sanat dünyasında kadınların sadece ilham perisi olarak yer alabildiği bir dönemde sanatçı olarak yer edinmeyi başarmış ve Sürrealist heykel yaratıcılarının ön sırasında yer almıştır. Hopkins (2020), “Fransa'da kadınların, Oppenheim'ın yaşadığı dönemde, İkinci Dünya Savaşı'nın bitimine kadar oy verme haklarının olmadığını” belirtir (s. 177). Sanatçı eril bakış açısının toplumsal yaşamı yüzyıllardır düzenleyip şekillendirdiğini, şekillendirilmiş bu toplumsal yapının kadının yaşamıymış gibi sunulduğunu düşünmüştür. Bu toplumsal yaşamın fantezilerini, kadınla ilgili tabuları sanatında ele alarak görünür hale getirmiştir. Sürrealizmin konu ettiği olguları kadın gözüyle yorumlayıp eleştirel mizah tarzıyla eserler üretmiştir.

Oppenheim çay setini kürkle kaplayarak oluşturduğu "Nesne" eseriyle, sıradan bir nesneyi işlevinden arındırarak dokunma ve tat duyusuna çağrıda bulunmuş, izleyiciyi kadın ve erkek cinselliğini mizahi tarzıyla sorgulatmaya çalışmıştır (Resim 1). Yılmaz (2013), Oppenheim'ın bu işinde sıradan bir nesnenin sanat yapıtına dönüştürülmesini, kadınlardan beklenen hizmete hayır denmesi olarak yorumlar (s. 200). Hopkins (2020) ise "Dada hazır-yapımı, bizim yorumumuzu sessizce beklerken, Oppenheim'ın Sürrealist nesnesinin açıkça psikolojik içeriğinde ısrar ettiği görülür” der (s. 126). Camper (1996) ise "yalnızca geleneksel heykelde değil, geleneksel (ve modernist) sofra takımlarında da fallik bir nitelik" olduğunu ifade eder ve şöyle devam eder: "Oppenheim'ın fincan, fincan tabağı ve kaşıktan oluşan kürk kaplaması, sert kenarları bulanıklaştırır. Sert yüzeyleri şehvetli dokunuşa bırakır. Kürkle kaplı, üç içbükey şekil birleştirildiğinde, neredeyse ters bir şekilde çekinik görünür; betimlenmemiş bir vulvayı düşündürür ve izleyiciyi içeri davet eder". Bu işiyle, Oppenheim günlük nesnelerin işlevini değiştirerek, kadın cinselliğini ve toplumu sorgularken, doğa ve kültür ikilemini de düşünülmesini istemiş gibi görünmektedir. Bu eser ona beklenmedik bir ün kazandırmış fakat bundan sonra üreteceği işlerde bu eserin baskısını da hissetmiştir. Öte yandan Oppenheim yine bu eserle New York, Modern Sanat Müzesine kabul edilen ilk kadın sanatçı olmuştur. 


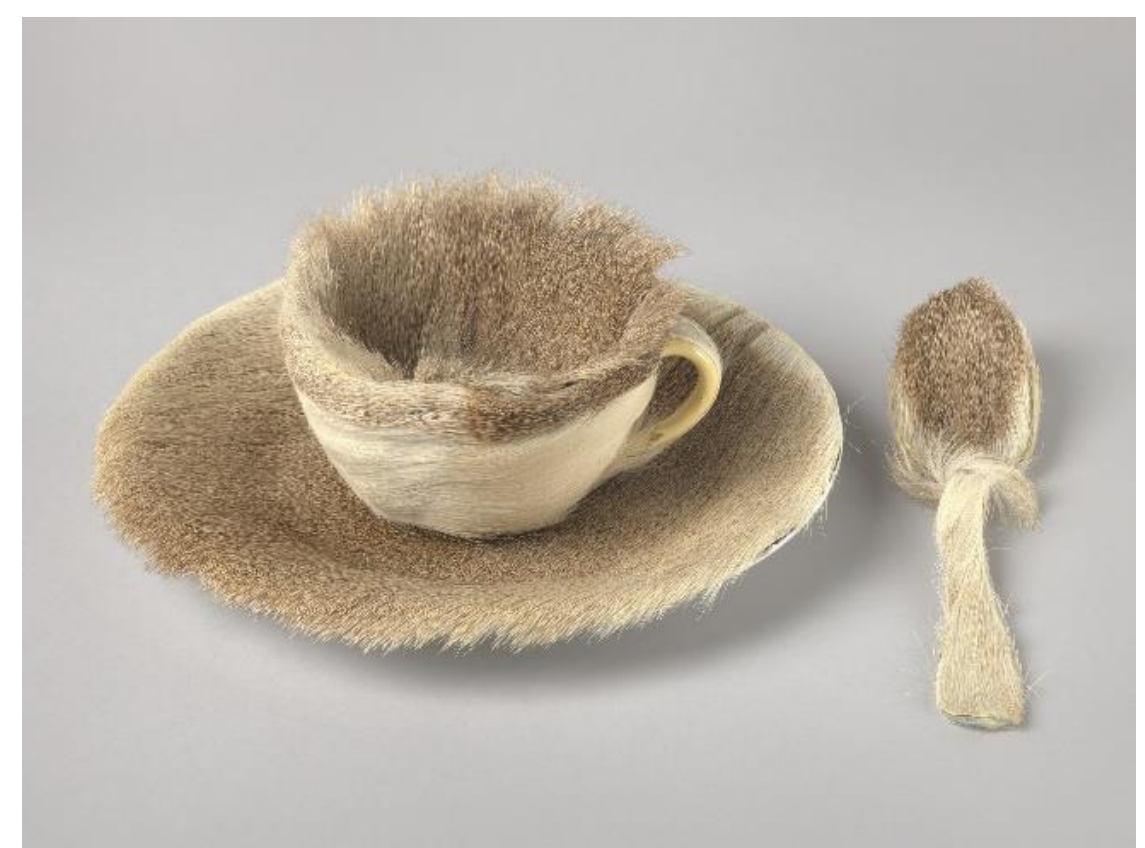

Resim 1. Meret Oppenheim, Le Déjeuner en Fourrure (Nesne), 1936, Hazır nesne, 12cmx24cmx20cm (https://www.moma.org/collection/works/80997)

Sanatçı "Hemşirem" adlı eserinde, beyaz ve yıpranmış bir ayakkabıyı bağlayıp servis tabağına yerleştirerek yemek gibi sunmuştur (Resim 2). Çalışmayı çok bilinen fetişist bir malzemeden yararlanarak yapmıştır. Sanatçı "Hemşirem” eseri için şunu söylemiştir: "Bu ayakkabılar bende, çocukluğumdaki bakıcımı dışarı sızdıran 'tensel havanın' gecikmiş farkındalığıyla, 'zevkle bir arada sıkıştırılan şeyler' düşüncesini çağrıştırdılar”' (Hopkins, 2020, s. 125). Hopkins (2020) bu eser için, "Sanatçı belki de kadın fetişizmi konusunu inceden inceye alaya alıyordu. Servis tabağındaki bir hindiye benzeyen iple bağlanmış ayakkabılar ve erkeksi bir hazneye kadınsı bir hava veren tabanındaki deliğiyle iki cinsiyetli formuyla sanatçının kendi kölelik fantezisi gibi yorumlanabilir" değerlendirmesinde bulunur (s. 126). Çift cinsiyetli formun yemek servisiyle sunulması, anima ve animus arketiplerini görünür k1lıp, kadın cinselliği üzerinden cinsel kimlikleri sorgulayarak aynı zamanda bir tedirginlik de yaratılmasını getirmiştir. 


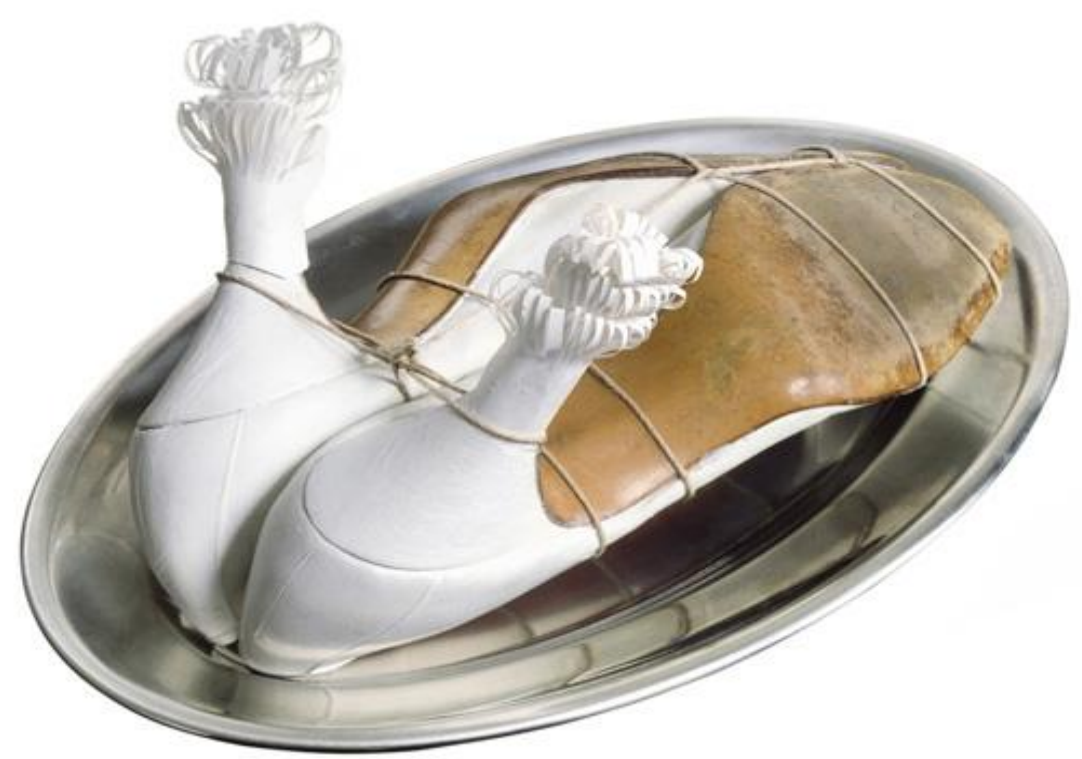

Resim 2. Meret Oppenheim, My Nurse (Hemşirem), 1936, Hazır nesne, $33 \mathrm{~cm} \times 21 \mathrm{~cm} x 14 \mathrm{~cm}$ (https://sis.modernamuseet.se/objects/1330/ma-gouvernante--my-nurse--mein-kindermadchen,)

Oppenheim, ahşap eli kürkle kaplayarak oluşturduğu "Ahşap Parmaklı Kürk" çalışmasında doğa ile kültürü karşılaştırmıştır (Resim 3). Hayvan ve insanı yan yana getirerek, antik ve modern, tüm uygarlığı sorgulamıştır. Duyularımızın ve hayal gücümüzün devreye girmesini, konuşan heykeli hissetmemizi istemiştir. Camper (1996) bu çalışmayı "daha şehvetli, baştan sona dekoratif formların karşısına sert, iddialı fallik bir şekil" olarak değerlendirir. Camper'e göre, "on parmak neredeyse tamamen kürkle kaplıdır, ancak kırmızı cilalı tırnakları, bir sineğin penisi gibi kürkten çıkar ve bir ilişkiyi zıddıyla değiştirir”. İnsan doğasını ve gücünü bize düşündürmüş, el ve kürkü bir arada kullanarak içgüdüsel ve hayvansal duyguları öne çıkarmış, dokunma duyumuza seslenerek cinsellik çağrısını da görselleştirmiştir. 


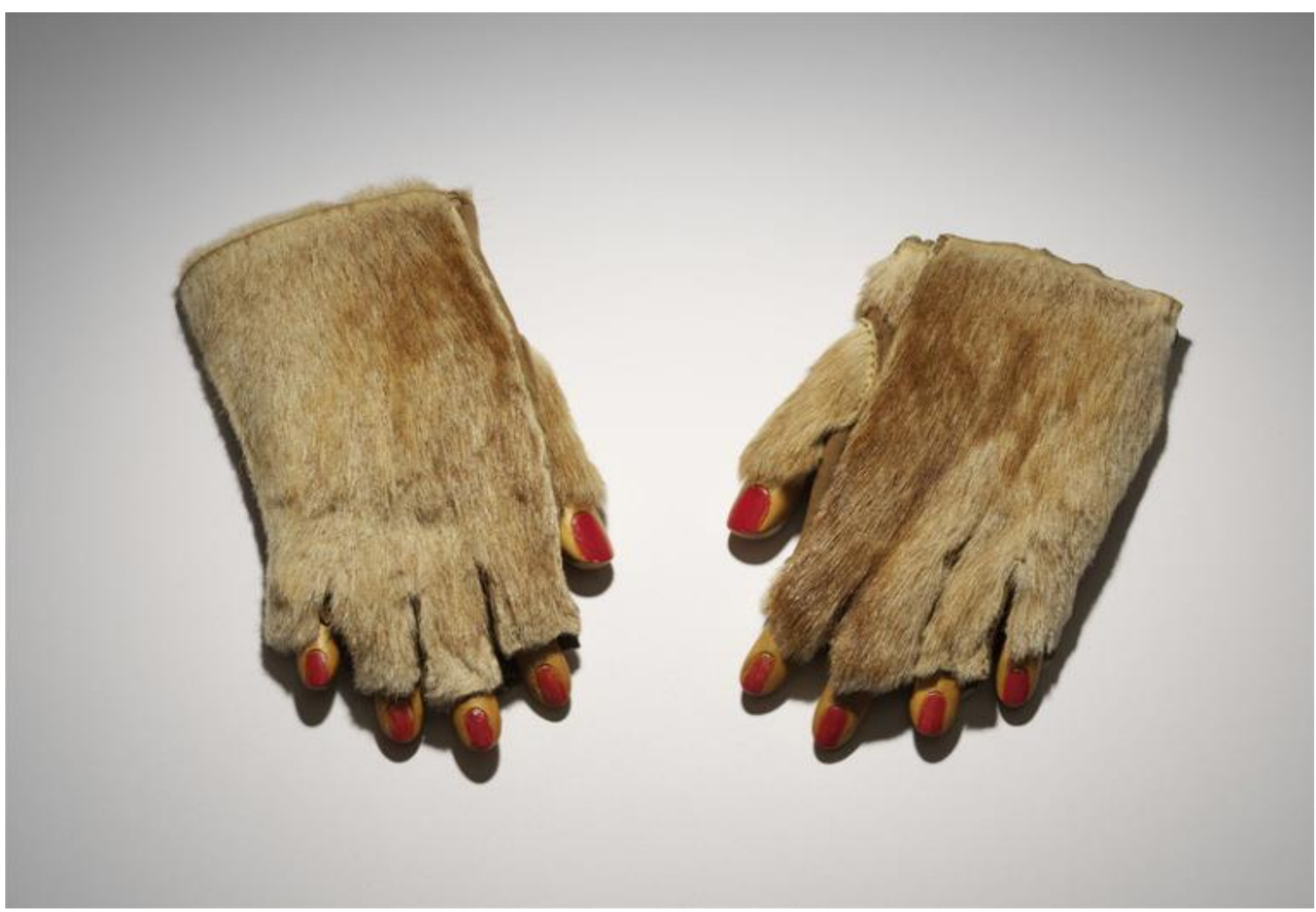

Resim 3. Meret Oppenheim, Fur Gloves With Wooden Finger (Ahşap Parmaklı Kürk), 1936, ahşap, kürk ve oje, $21 \mathrm{~cm} \times 10 \mathrm{~cm} \times 5 \mathrm{~cm}$ (https://artdone.wordpress.com/2013/04/01/meret/meret-oppenheimpelzhandschuhe-1936-ursula-hauser-collection-switzerland/)

Sanatçının esin kaynağı yaşamı, yaşadıklarının ona hissettirdiği duyguları olmuştur. Rüyaları, hayalleri, duygusal ilişkileri, bilinçaltı ve psikanaliz bilgileri eserlerini beslemiş ve şekillendirmiştir (Özer, 2019). Marx Ernst'le kısa süreli duygusal bir ilişki yaşamış, gerilimli olan bu ilişkiyi sonlandırmıştır (Zürcher, 2004). Sanatçının duygusal gelgitleri, gelecekte daha da kötüleşecek olan depresyonun başlangıcı olmuştur. Babası kızının ruhsal durumundan kayg1 duyarak, çözümü için Jung'a göndermiştir. Görüşme sonucu Jung, Oppenheim'e şu sözü söylemiştir: "Biri tüm kadınlardan melek olmalarını talep ediyor". Bu söz, eril söylemin kadına bakışını yansıtırken, depresyonunda işaretidir (Zürcher, 2004). Oppenheim eril sistemin kadından istediği rolleri reddetmiştir. Başkalarına değil kendine ilham vermek istemiş, yaşadığı hissettiği olumsuzluklar, duygusal çalkantıları onu depresyona sürüklemiştir.

1937 y1lı Avrupa'da Hitler'in öncü olduğu 1rkçı söylem ve uygulamaların etkisini hissettirdiği olayların başlangıcıdır. Sanatçının babasının Yahudi olması ve mesleğini yapamaması ekonomik sorunlara neden olmuştur (Velimirovic, 2016). Oppenheim ailesinin yanına İsviçre'ye geri dönmek zorunda kalmıştır. Sanatçı, "Nesne" eserinin getirdiği başarının diğer eserlerinin başarılarını gölgelediğini düşünmüş, tek bir eserle tanınmak sanatçıda üretememe kaygısına neden olmuştur. Toplumsal süreçteki değişimlerin meydana getirdiği baskılar da depresyonda olan sanatçının psikolojik sorunlarını derinleştirmiştir. Sanatçı bu dönemini "öz saygının yok edilmesi” olarak 
nitelemiştir (Camper, 1996). Yaklaşık on sekiz yıl süren bu durum yaratımlarının bir kısmını yok etmiştir (Zürcher, 2004).

Sanatçı 1950'lerde yeniden üretmeye başlamış ve Paris'te tekrar Sürrealistlerle bir araya gelmiştir.1956' da bir çift kahverengi botu parmak uçlarından birbirine yapıştırarak "Çift" adlı eserini üretmiştir (Resim 4). Day (2017) eseri anlatırken şu sözleri kullanmaktadır: "Parmak uçlarından birleştirilen çizme yürümeye davettir, yapılan müdahale ise birlikte yürümeyi aksatır". Camper (1996) ise, "iki fallik formun birbirini etkisiz duruma getirdiğini ve kadınların ataerkillik altındaki itaatkâr statüsünü yansıttığını" ifade etmiştir. Eserinin adı ve botları parmak uçlarından öpüştürmüş olması görülen ya da görülmeyen ilişkilerin sanatçı tarafından somutlaştırılmasıdır. Sanatçı güzel ve estetiği, akıl ve anlamla bütünleştirip, hazır nesneyi heykelleştirerek izleyiciyi düşünmeye yöneltmiştir.

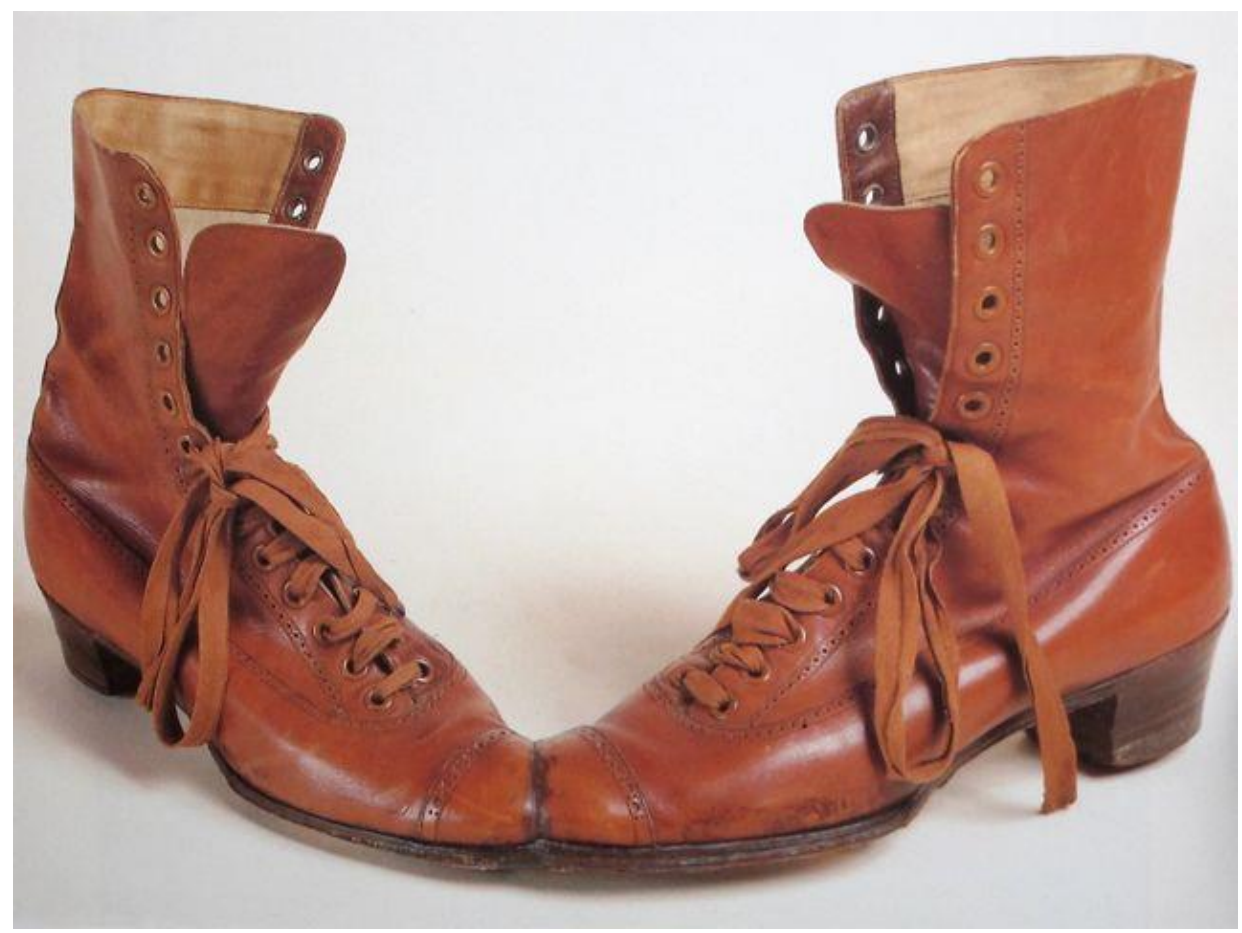

Resim 4. Meret Oppenheim, The Couple (Çift), 1956, Hazır nesne, 40cmx20cmx15cm (https://www.wik iart.org/en/meret-oppenheim/the-couple,)

Oppenheim 1959'un Nisan ayında "Bahar Doğurganlık Ritüeli” adlı eserini tasarlayıp, arkadaşlarını davet etmiş, ritüelin gerçekleşmesini sağlamıştır. Yerleştirme olarak gerçekleştirdiği bu işini şöyle tasarlamıştır; masaya çıplak genç bir kadını yatırmış ve kadının tüm vücudunu şekerlemeler ve meyvelerle süslemiştir. Arkadaşlarını çıplak ellerle yemeğe davet ederek ritüelini gerçekleştirmiştir. Breton 1959'un Aralık ayında yapılacak "Exposition InteRnatiOnal du Surrealisme" (EROS) adını verdikleri sergide bu çalışmanın yeniden gösterilmesini istemiştir. Sanatçı çalışmasını canlı kadın yerine, manken kullanarak tasarlamıştır (Resim 5). EROS ziyaretçileri ölüler için yapılan bir 
ayine çağırmıştır. Passeron'a (1982) göre, “Ziyaretçilerden döl yolunu hatırlatan koridordan geçmeleri, koridorun sonundaki vajinal kapıya ulaşıp, labirente girmeleri istenmiştir. Uğultularla dolu labirenti, kat etmek zorunda kalan ziyaretçiler, fetişlerle dolu bir odadan geçip yamyam festivalinin yapıldığı kırmızı odaya ulaşmaktadır. Odada masa, masa üzerinde örtü ve örtünün üzerinde çıplak güzel bir kadını simgeleyen manken yatırılmıştı. Bu güzelin üstü çeşitli meyvelerle donatılmıştır” (s. 74). Oppenheim bu çalışmasıyla kadını tüketim nesnesi olarak betimlediği için eleştirilmiştir. Kendisinin ifadesiyle ise amacını doğanın yarattığı bolluğu, yaşam ve ölüm döngüsünü göstermektir. Üstelik sadece kadın için değil erkek için de baharı doğurganlık ayini olarak tasarladığını ifade etmiş, sonuçta oluşan izlenimlerden rahatsız olduğunu belirtmiş ve Sürrealistlerle olan birlikteliğini bitirmiştir.

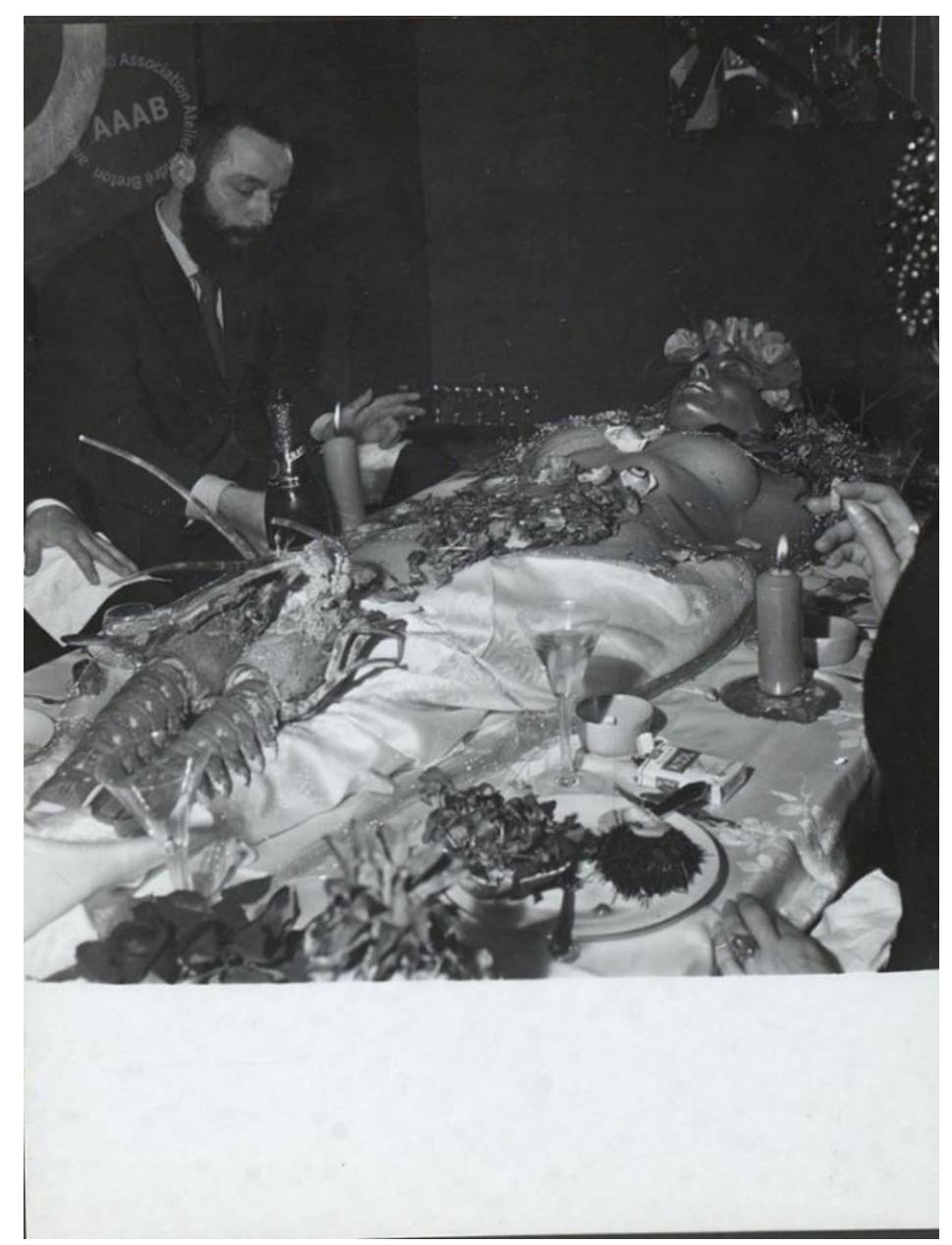

Resim 5. Meret Oppenheim, Uluslararası Sürrealizm Sergisi, Yamyam Sofrası, 1959-60 (https://www.andrebreton.fr/en/work/56600100977990?back_rql,) 


\section{Oppenheim'in Olgunluk Dönemi Çalışmaları}

Oppenheim'ın sanatı kendi yaşadığı olaylar bütününün kronolojik yapılanması gibidir. Yaşamının bir döneminde Duchamp ile duygusal birliktelikleri olmuştur (Day, 2017). Duchamp'ın gönderdiği okyanus gemisi kartpostalından ilham alarak “Teknede Bulut” adlı eserini oluşturmuştur (Resim 6). Yaşadığı Basel şehrinin içinden geçen Ren Nehri’ne ithaf ederek insanın doğaya yaklaşımını mizahi tarzla birleştirmiş, insan doğa ikileminin dengesini sorgulamıştır. Aynı zamanda okyanus ötesine selam göndermiştir (Fluri, 2013).

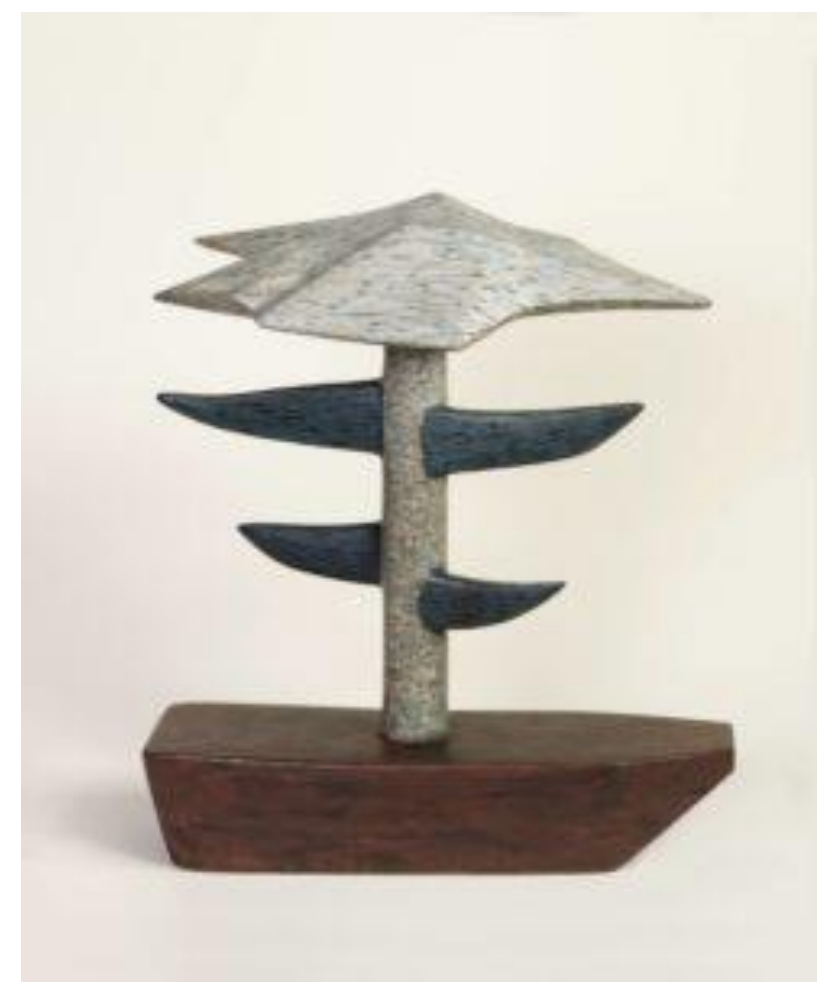

Resim 6. Meret Oppenheim, Wolke auf einem schiff (Teknede Bulut), 1963, metal armatür üzerine siva, $37 \mathrm{cmx} 33 \mathrm{cmx} 12,1 \mathrm{~cm}$ (https://www.artsy.net/artwork/meret-oppenheim-wolke-auf-einem-schiff-cloud-ona-boat)

Duyguları sanatla ifade etmek özeli genelleştirmek, cesaret isteyen bir durumdur. Oppenheim sanatında olduğu gibi yaşamını da sanat eserine dönüştürme konusunda cesur olmuştur. Cesaretinin göstergesi gibi olan bu eserini satranç tahtası, keklik omurgasının yuvası olan hamurdan yapılmış küçük totem figürü ve yemek takımıyla oluşturmuştur (Resim 7). Kriebel (2014), "Kraliçeyi andıran ilkel kadın formunu, sırtı kemikle dudağa benzetmiş, tehdit eder gibi ye ve boğul, Marcel. Satranç bir savaştır.” diye yorumlar (s.23). Burada aynı zamanda Duchamp'ın satranç tutkusuna gönderme yapmış, eleştirel tutumunu sanatı aracılıyla gerçekleştirmiştir. 


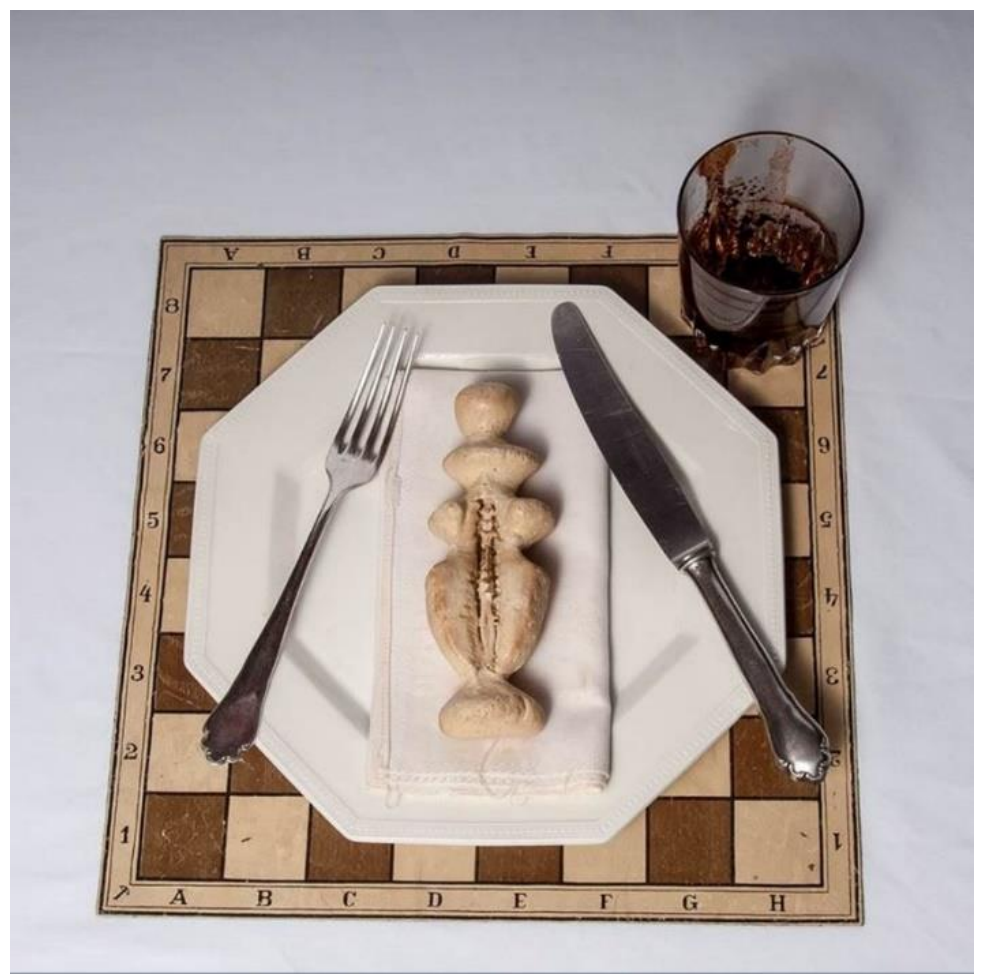

Resim 7. Meret Oppenheim, Bon Appetit, Marcel (La regina bianca) (Afiyet Olsun, Marcel (Beyaz kraliçe)), 1966, Hamur ve çeşitli hazır malzemeler, $32 \mathrm{~cm} \times 32 \mathrm{~cm} \times 10 \mathrm{~cm}$ (https://artmoove.com/magazine/2017/02/22/meret-oppenheim-opere-in-dialogo-da-max-ernst-a-monahatoum/,

Camper'a (1996) göre, “Oppenheim için sanat, oyun gibidir. Çoğu eserinde alışılagelmiş şekilleri yeni şekillerde görme konusunda çocuksu bir istek, gizli bir mizah duygusu duyar ve sergiler." Sanatçı "Meret Oppenheim'un Kafatası Röntgeni” adlı eserini mizahi bir duygu içinde düşünmüştür (Resim 8). Kendi ölümüyle oyun oynamak ister. Sanatç1 iki bin yılından önce öleceğini düşünür. Ama iki bin yılından sonra ölmek onun için muhteşemdir (Nassau Community College, tarihsiz). Bu eserini çocuksu bir istekle tasarlamıştır. Çalışmasında kendi kafa röntgenini çektirerek görünen ve görünmeyenin ötesinin güzelliğini içimize nüfus etmesini istemiştir (Calas, 1975). Aynı zamanda sanattaki cinsiyetin anlamını sorgulamış, sanatın cinsiyetsizliğine inanan tavrını göstermek istemiştir. Eserdeki görüntü ve isim izleyiciyi bir anlama ulaştırırken, ulaştığ 1 anlamı da sorgulamaya yönlendirmiştir. Eserdeki takılar cinsiyeti çağrıştırmaktadır fakat değişen değer yargıları bunu cevaplayabilir mi sorusunu düşünmemizi ister gibidir. 


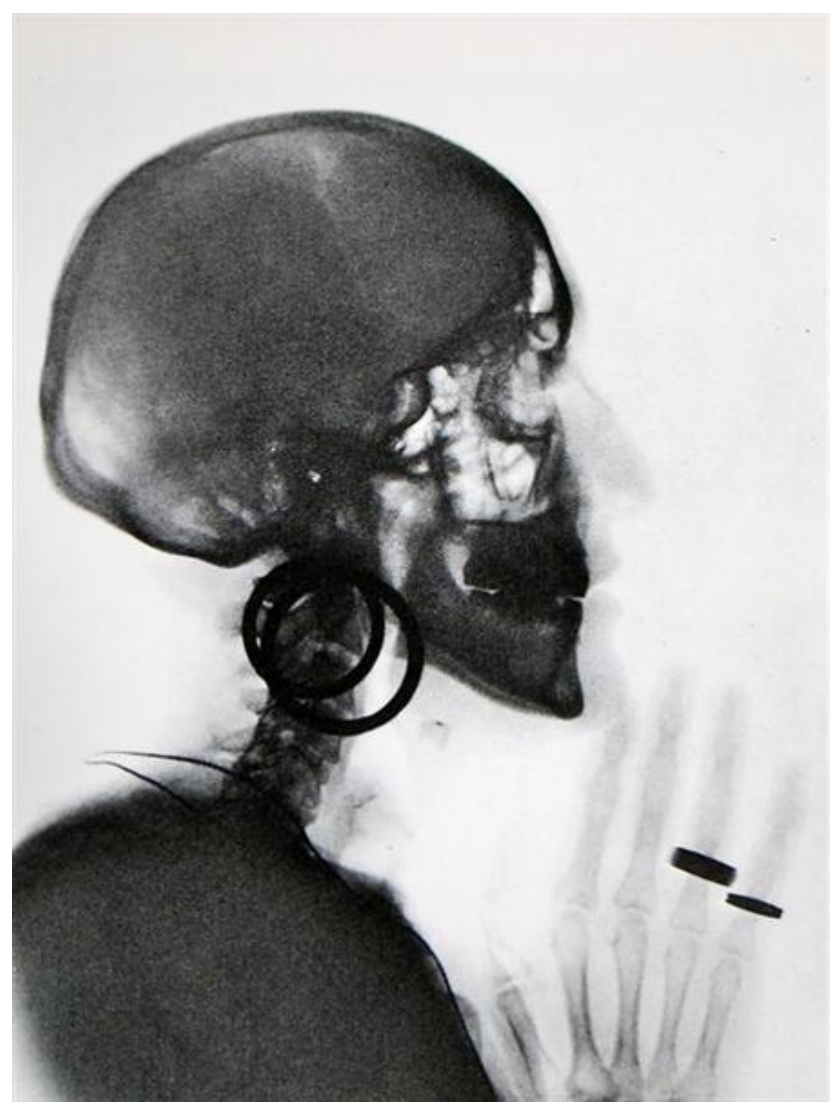

Resim 8. Meret Oppenheim,X-Ray Self Portrait (Meret Oppenheim'un Kafatası Röntgeni), 1964, 24,77cmx20,32cm (https://www.wikiart.org/en/meret-oppenheim/x-ray-of-m-o-s-skull-1964)

Oppenheim eserlerinde zamanla daire, çember, kare ve dörtlü sembollerini daha sık kullanmaya başlamıştır. Bu sembolleri Jung, düzen arketipi olarak tanımlar. Jung'a (2006) göre, "Düzen arketipi kişi tamlığıdır ve Özben'i ifade eder. Özben bilinç ve bilinçdışının ortak noktada birleşerek dengeyi sağladığı durumdur. Özben'e ulaşmak kişinin kendisini gerçekleştirmesi demektir. Bu simgelere Sanskritçede mandala denir, bütünlüğü temsil eder. İnsanlık tarihinin en eski dinsel simgeleridir" (s. 76). Oppenheim'ın "Doğanın Yolu” eserinde Özben arketipini işaret eden sembolleri kullanmıştır (Resim 9). Bu semboller sanatçının üretimlerinde esin kaynağı olmuştur. Curige (2013), “Oppenheim, Jung'un arketiplerini kendi sanatının kapılarını açmak için bir sıçrama tahtası olarak kullanıp, ilham alır" diye ifade eder. Bu eseri insan siluetini veya bir ağaç gövdesini çağrıştırmaktadır. Dua eder gibi bir çiftin bütünlüğünü görselleştirdiği gibi doğaya yönelik bir çağrıda olabilir. Soyut olan bu eser, gökyüzüne yükselen bir formdur. Bu eser sanatçının ölümünden bir yıl sonra, Fransa'nın Paris kentinin "Ministére- Le Jardin Carré (Bakanlık-Meydan Bahçesi)" ne yerleştirilmiştir (Ministére De L'enseignement Supérieur,de La Recherche Et De L’innavation, 2009). 


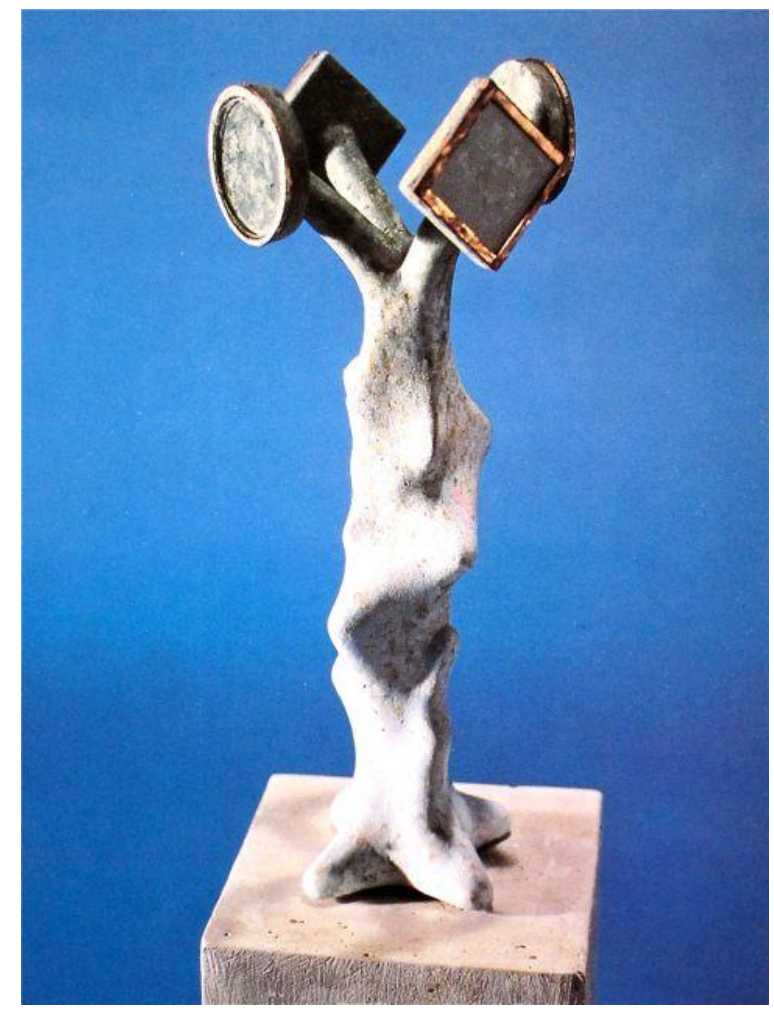

Resim 9. Meret Oppenheim, Spiral Nature's Way (Doğanın Yolu), 1971, Alçı Modelleme (https://www.wikiart.org/en/meret-oppenheim/spiral-nature-s-way-1971)

Oppenheim mahremiyetini sanatla buluşturmada ve özgürlük anlayışında korkusuz bir tavır izlemiştir. 1975 'te "Basel Kenti Sanat" ödülünü alırken, kadın hakları ve özgürlükleri adına radikal bir konuşma yaparak şöyle demiştir: "Bir kadın olarak şunu ifade ediyorum. Kadınlara boyun eğdirmek için binlerce yıldır kullanılan tabuların geçersiz olduğunu yaşam tarzımızla kanıtlamakla yükümlüyüz. Özgürlük verilmez; onu almak zorundayı" (Gommel, 2013).

Sanatçının eserleri incelendiğinde göze çarpan şey süreksizlik ve değişkenliktir. Hep bir arayış, keşif ve oyun hali vardır. Her işinde kendini tanıma ve yenileme çabasını göstermektedir. Oppenheim göre sanat heyecan yaratır. Zihni harekete geçirir. Ve hayal gücü de sanatçının yürüyüşe çıktığı manzaradır (Pearce ve Spoerri 1990). Sanatçı soldaki eserinde kadını doğayla eşleştirirken manzarasını görünür kılmak istemiştir (Resim 10). Kareden dikdörtgen oluşturduğu çalışmada, zihnini harekete geçirerek, kendi bütünlüğüne ulaşmaya çalışmıştır. Doğanın bir parçası olduğunu özellikle kadındaki bazı özellikleri abartarak animus arketipini görünür kılmak istemiştir. Mizahi anlatımını estetik tarzıyla bütünleştirmiştir. Sağdaki eserinde Antik Dönem ile günümüzün ölüm olgusunu kare ve dörtlü sembollerle birleştirmiştir (Resim 10). Sanatçı, zihnimizi harekete geçirsek de bazı şeyleri bilemeyeceğimizi vurgulamak istemiştir. Antik Dönem'den günümüze kadar hep sorgulanan, kesin bilgisi olamayan ölüm olgusunu, hayal gücünün oluşturduğu manzarayı, eseriyle bütünleştirip görselleştirmeye çalışmıştır. 

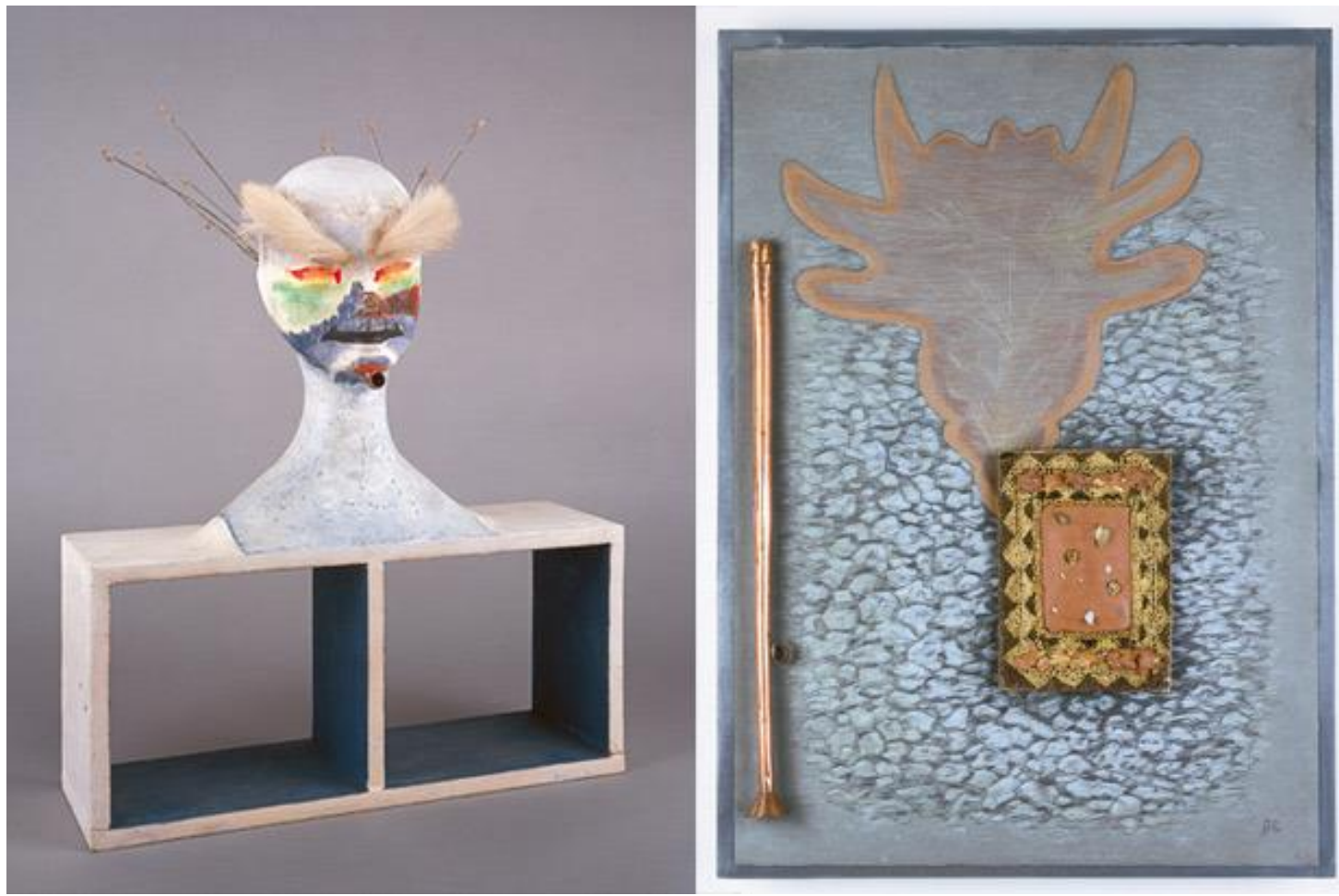

Resim 10. Solda: Meteora, 1977. Ahşap çerçeve, strafor, yağ, kürk, bakır, metal, kumaş ve macun, $105 \mathrm{~cm} \times 50 \mathrm{~cm} \times 15 \mathrm{~cm}$.

Sağda: Altes Grab im Wald (Ormandaki Eski Mezar), 1977. Renkli kalem, taşlar, modelleme kili, kağıt üzerine bakır boru, ahşap ve pleksiglas çerçeve, $70 \mathrm{~cm} \times 50 \mathrm{~cm} \times 4 \mathrm{~cm}$. (http://blog.kunstmuseumbern.ch/meret-oppenheim-digital/)

Oppenheim 1982’de Berlin Sanat ödülüne layık görülmüş, Almanya'nın Kassel şehrinde düzenlenen Documenta 7'ye davet edilmiştir. Sanatçı ölümünden iki yıl önce İsviçre'nin Bern kentinde Waisenhausplatz meydanına yerleştirilen "Spiral Sütun” eserini gerçekleştirmiştir (Resim 11). Olgunluk dönemini yansıtan bu eser görselliğinin değişkenliğinden dolayı tartışmalara neden olmuştur. Sanatçı bu tartışmalar hakkında şu ifadelerde bulunmuştur: "Bu beni üzmedi. En kötüsüne hazırlanacak kadar yaşlıyım" (Zürcher, 2004). “Meret Oppenheim'ın Çeşmesi” olarak da bilinen bu eser, beton sütün etrafına spiral şekilde sarılmış alüminyum çim çelenkten oluşmuştur. Üstten alta doğru çim çelenk üzerinden akacak şekilde su damlacıkları oluşturulmuştur. Bu oluşum sayesinde zaman, mevsim ve doğal koşuların meydana getirdiği olaylar heykelde görünür kılınmaya çalışılmıştır. Bu görünürlüğün değişkenliği kentin insanlarında farklı duygular yaşamasına neden olmuştur. Spiral sanatçı için dişil yönüyle doğurganlığı ve yaşamın yenilenişini, eril yönüyle de yaşamın sürekliliğini ve koruyuculuğunu yansıtır gibi görünmektedir. Heykel bir organizma gibi sürekli değişim göstererek yaşarken, anima, animus arketiplerini çağrıştırmaktadır. Oppenheim "doğa-kültür”, "kadın-erkek” gibi ikilemleri birbirlerinin karşıtı gibi görmemiştir. Bu karşıtlıkların uyumlarını oluştururken meydana gelen oluşumu hayatın kendisi olarak görmüş ve karşıtlıklarının meydana 
getirdiği uyum mücadelesini sanatına yansıtmaya çalışmıştır. Yaşamında meydana gelen oluşumların nedenlerinden çok anlamını sorgulamış, sanatını oluşturduğu anlamlar üzerinden şekillendirmek istemiştir.

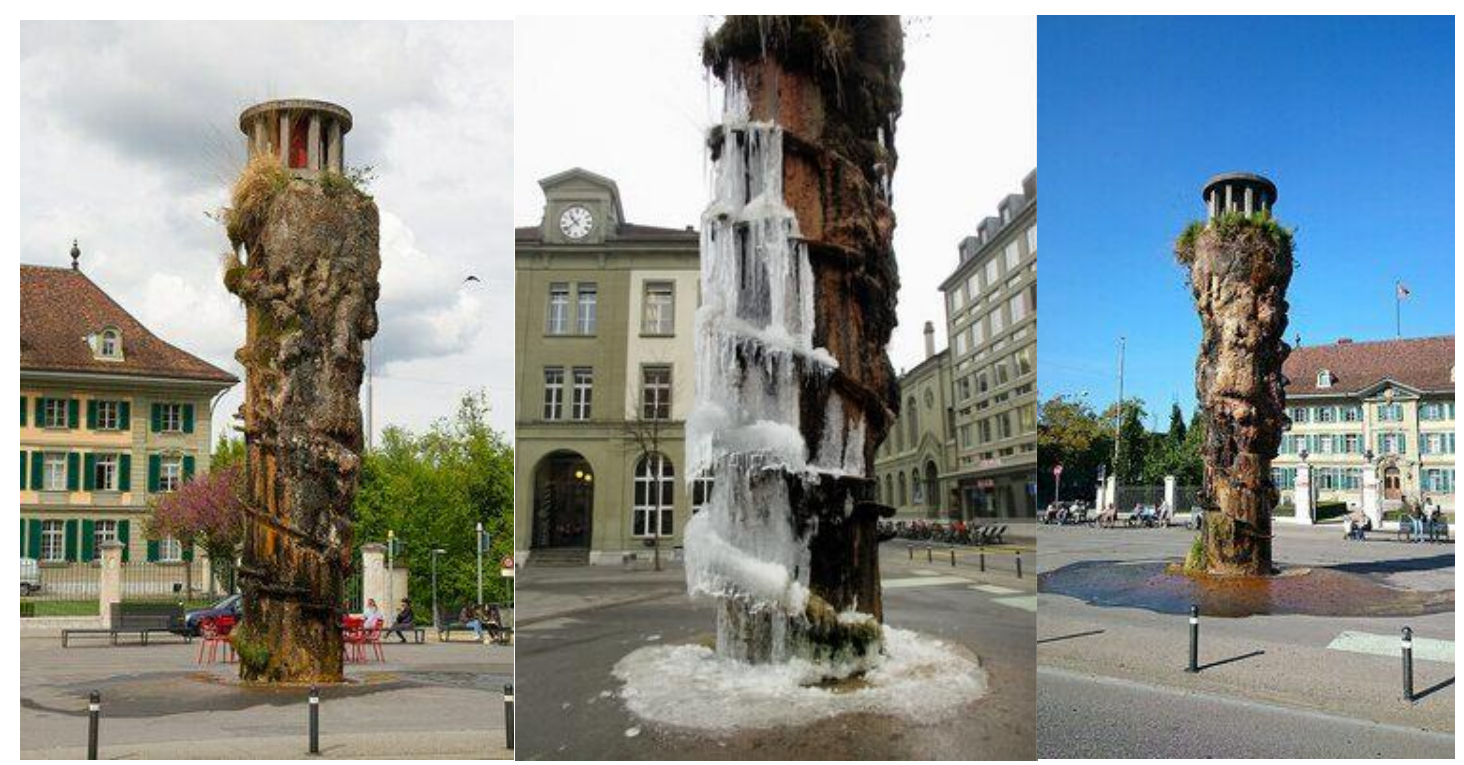

Resim 11. Meret Oppenheim, The Spiral Column (Spiral Sütun), 1983, beton, $8 \mathrm{mx} 1,4 \mathrm{mx} 1,4 \mathrm{~m}$ (https://www.widewalls.ch/artists/meret-oppenheim,)

Oppenheim'in cinsiyet düşüncesi ve toplumun sosyokültürel düşünceleri onda acı, öfke duygularını çağrıştırır. Sanatçıya göre, "Feminizm, toplumumuzdaki kadınların durumunu değiştirmek için gerekli bir çabadır. Toplum değiştirilmelidir! Ama sanatın cinsiyeti yoktur. Sanat hem kadın hem erkektir" (Pearce ve Spoerri 1990).

Oppenheim yazgısını kendi hayalleri ve rüyalarının senteziyle oluşturmuştur. Sanatçı toplumun bilinç ve bilinçaltını kendini merkeze alarak sorgulamış, her ruhun çift cinsiyetli olduğunu bu çift ikilemin sentez ve dengesinin sanatını şekillendirdiğini, sanatın cinsiyet özelliğinin olmadığını sadece temel bilgilerin olduğunu düşünmüştür. Tüm sınıflandırmalara karşı oluşunu kadın sanatı sınıflandırmasına karşı gelerek de göstermiştir. Burada özde sanatın var olduğunu savunmuş, kadın sanatçı olarak sanat tarihinde kendine yer açmıştır. Eserlerinde kadına ait tabuları irdelerken insanları tedirgin etmiş, şaşırtmış, tanıdık nesneleri bağlamından kopararak, oluşturduğu yeni bağlamı kişide somutlaştırmaya çalışmıştır. Oluşan yeni bağlamı izleyicinin veya toplumun bilinçaltına seslenerek sorgulatmak istemiştir. Bu sorgulatmayı mizah, erotizm, kadın cinselliği ve kimliğine karşı eleştirel yaklaşımları benimseyen tavrıyla gerçekleştirmiştir. Eserlerinde akıl ve duyular arasında yaratıcı eşleştirmeler yapmış, dokunma ve tat alma duyularımıza seslenmiştir. Tat alma ve dokunma duyularımıza yönelirken, eserlerine verdiği isimlerle de aklımıza yönelmiş, kadın cinselliğinin tabularına karşı atıfta bulunacak şekilde gündelik nesneleri kullanmıştır. Bu nesnelerin, bilinçaltındaki çağrışımlarını konuşturarak sıradan olmadığını yansıtmak istemiştir. 


\section{Sonuç}

Oppenheim sanat yaşamı boyunca rüyalarına, hayallerine ve bilinçaltına bakmıştır. Bu bakışını toplumsal bilinçaltına yönelterek cinsellik üzerinden kadına yönelen cinsel tabuları irdelemiştir. Kadının toplumsal görevlerini, kadın cinselliğini ve cinsel kimlikleri mizahi tarzda yorumlayıp eserlerine yansıtmıştır. Sanatçının yaratım sürecini ikilemleri belirlemiştir. İkilemleri zıtlık oluşturmaz ama tam da değildir. İkilemlerinin gerilimi yaratım sürecinin başlangıcını oluşturmuştur. "Kadın sanatı"- "Erkek sanatı" ikileminden "Sanat", "Kadın sanatçı"- "Erkek sanatçı" ikileminden "Sanatçı" varlığına ulaşmaya çalıştığı görülmektedir. İkilemlerini sorgulama çabası toplumsal bilinçaltını sürekli, yeniden yorumlamasını sağlamıştır. Bu yorumlama Oppenheim'1 "Doğa-Kültür", "Doğaİnsan” gibi ikilemlere götürmüş, görünmeyeni görünür kılmaya çalışırken geleceği işaret etmiştir.Sanatsal sürecinde eril sistemi hedef alan muhalif tavır ve eylemlerde bulunmuş, eserleri aracılığıyla eleştirilerini görselleştirip, tanımlamıştır. $\mathrm{Bu}$ tanımlama ve görselleştirmeyi yaparken çizimler, heykelleşmiş takılar, hazır nesnelerden heykeller ve her tür malzemeyi kullanarak heykellerini oluşturmuştur. Eserlerine hayal gücünü, sezgiyi, duyguları, dokunma hissini ve tat alma duyusunu da taşımıştır.

Oppenheim sanat1, "hazır nesne heykelleri” ile düşünme eylemi olarak görmüş, olgunluk dönemi eserleriyle de beceri ve yetenek olarak düşünmüş, eserlerini bu bakış acısıyla yorumlamıştır. Özellikle hazır nesnelerle oluşturduğu eserleriyle çağdaş sanata esin kaynağı olmuştur. Kadın sanatına karşı tavır sergilese de kadın hakları konusundaki tutumu, eserlerini yorumlama biçimiyle kadın sanatçıları ve feminist sanatı etkilemiştir.

Oppenheim sanatsal yaklaşımında herhangi bir üsluba bağlı kalmamış, hemen her eserinde sanatsal dilini ve temasını yenileyerek sanatsal kaderini tayin etmeye çalışmıştır. Her sanat eserinin kendi formu olduğuna inanmıştır. Sanatçılara kendi uygun ortamlarını seçme özgürlügünün yolunu açmıştır. Disiplinler arası yaklaşımı ve çalışması ile çağdaş sanatı etkilemiştir. Kişiliği, kamusal bir figür olarak kültürel ve politik önemi bazen eserlerinin önüne geçmiştir. Sanatçı çalışmalarını sürdürürken 1985 yılında yaşama gözlerini yummuş, bazen kişiliği sanatının önüne geçse de kendine has sanat yaklaşımıyla sanat tarihinde "Kadın sanatçı" olarak yer edinmiştir.

\section{Kaynakça}

Antmen, A. (2017). 20. Yüzyıl batı sanatında akımlar. (8.Baskı). Sel Yayıncılık.

Calas, N. (1975). Meret Oppenheim: Confrontations. Artforum. https://www.artforum.com/print/197806/meret-oppenheim-confrontations-37207

Camper, F, (1996, Temmuz 5) A woman and her objects Meret Oppenheim: Beyond the teacup/at the museum of contemporary art, through January 12. Reader Chicago's 
Alternative Aonprofit Newsroom 26-(9). https://chicagoreader.com/arts-culture/awoman-and-her-objects/

Curiger, B. (2013, Mayıs 29). A great deal with enormously little. Frieze. https://www.frieze.com/article/mit-ganz-enorm-wenig-viel,

Day, J. (2017, Mart 27). Meret Oppenheim - an outsider interested in the outsides of things. Apollo Magazine. https://www.apollo-magazine.com/meret-oppenheimin-switzerland/bv

Danto, A, C. (2013). Sanat nedir. (Z. Baransel Çev.) (3. Baskı). Sel Yayıncılık.

Darcella, A ve Galopin, B. (2018, Ekim 06). Cr muse: Meret Oppenheim, surreal art and fashion. in celebration of her birthday, $\mathrm{Cr}$ remembers the woman whose contributions to art had a lasting effect on fashion. CR Fashion Book. https://www.crfashionbook.com/culture/a23395360/cr-muse-meret-oppenheimart-fashion/

Nassau Community College. (tarihsiz). Surrealism's monstrous beauty. https://faculty.ncc.edu/LinkClick.aspx ?fileticket=CK6aUCog4zQ\%3D\&tabid=2 $646 \& \operatorname{mid}=3394$

Fluri, C. (2013, Ağustos 15). Kunstprojekt-Meret Oppenheim erhalt durch Basler Künstler ein neures Leben. Tagblatt. https://www.tagblatt.ch/kultur/buch-buehnekunst/meret-oppenheim-erhalt-durch-basler-kunstler-ein-neues-lebenld. 1783668

Gommel, S. (2013, Nisan 05). Meret Oppenheim. tracker of dreams. "It's the artists who do the dreaming for society" (Meret Oppenheim). Hatje Cantz. https://www.hatjecantz.de/meret-oppenheim-5774-1.html

Hopkins, D. (2020). Dada ve gerçeküstücülük. (S. K. Ang1 Çev.) (2.Bask1). Dost Kitabevi Yayınları.

Jung, C, G. (2006). Analitik psikoloji. (E. Gürol Çev.) (2. Baskı). Payel Yayınevi.

Kriebel, S. (2014). Meret Oppenheim retrospective Berliner Festspiele, Martin-Gropius Bau, Berlin. Enclave Review ER10. http://enclavereview.org/meret-oppenheimretrospective-berliner-festspiele-martin-gropius-bau-berlin/

Ministére De L'enseignement Supérieur,de La Recherche Et De L'innavation, (2009, Şubat 26). Ministère- Le Jardin Carré. https://www.enseignementsuprecherche.gouv.fr/fr/ministere-le-jardin-carre-45724

Özer, I. (2019, Temmuz 27). Rüyalardan Çıkan Bir Kadın Sürrealist: Oppenheim. Gazete Duvar. https://www.gazeteduvar.com.tr/yazarlar/2019/07/27/ruyalardan-cikanbir-kadin-surrealist-oppenheim

Passeron, R. (1982). Sürrealizm sanat ansiklopedisi. (S. Tansuğ Çev.). Remzi Kitabevi. 
Pearce, R, P ve Spoerri, A. (1990). IMAGO narrative. Rutgers, The State University of New Jersey. http://aspoerri.comminfo.rutgers.edu/IMAGO/ filmtext.htm

Timuçin, A. (2014). Düşünce tarihi 3. (6. Baskı). Bulut Yayınları.

Velimirovic, A. (2016, May1s 18), Meret Oppenheim / Méret Elisabeth Oppenheim. Widewalls. https://www.widewalls.ch/artists/meret-oppenheim

Y1lmaz, M. (2013). Modernden postmoderne sanat. (2. Bask1). Ütopya Yayınevi.

Zürcher, B. (2004). A chronicle of life and work. Moderna Museet. https://www.modernamuseet.se/stockholm/en/exhibitions/meret-oppenheim/achronicle-of-life-and-work/ 